\title{
Universities and economic development activities
}

\section{A UK regional comparison}

\author{
Moira Decter, Frank Cave, Mary Rose, Gill Peers, \\ Helen Fogg and Susan M. Smith
}

\begin{abstract}
A number of UK universities prioritize economic development or regeneration activities and for some of these universities such activities are the main focus of their knowledge transfer work. This study compares two regions of the UK - the North West and the South East of England which have very different levels of economic performance. Quantitative data from the UK government's Higher Education Business and Community Interaction Survey are used to track economic development funding and activity from universities in these two regions. Strategy documents prepared for the fourth round of the government's Higher Education Innovation Fund are analysed to aid interpretations. Elements of evolutionary theory are used to explore the reasons for the differences and a case study of one university programme, Leading Enterprise and Development, is provided as an illustrative example.
\end{abstract}

Keywords: knowledge transfer; economic development; regeneration; UK

The authors are with the Institute for Entrepreneurship and Enterprise Development, Lancaster University Management School, Lancaster LA1 4YX, UK. Corresponding author: Moira Decter. E-mail: m.decter@lancaster.ac.uk.

The involvement of universities in the economic development of their regions is an issue of growing importance. Technological advance is often linked to economic progress and governments seeking ways to boost regional economies increasingly look to universities, amongst other organizations, to support economic growth. In recent years the UK government has recognized that '.. the UK's economic success will depend on its ability to create new knowledge and translate it into innovative goods and services' (Brown, 2006, p 42). In the UK in general, spending on $R \& D$ has been low over the last two decades and the 'need to follow through successful R\&D with effective deployment programmes' is recognized (DTI, 2001, p 19). Whilst UK government policy over the last decade has included programmes to encourage general knowledge transfer (KT) from universities to industry (DTI, 2001), KT programmes specializing in regeneration at UK universities tend to focus on providing support to small and medium-sized enterprises (SMEs).

Several UK universities engage in economic development or regeneration activities and these activities can, in some cases, form the majority of their knowledge transfer (KT) work. The range of such activities is outlined in Table 1. Economic development activities have been funded in the UK largely by the European Union (EU) through the European Regional Development Fund (ERDF) and UK Regional Development Agencies (RDAs) since the late 1990s. ${ }^{1}$ 
Table 1. UK KT categories - an extended categorization/definition.

\begin{tabular}{|c|c|c|c|}
\hline Classification & Technology transfer & Business support & $\begin{array}{l}\text { Regeneration/economic } \\
\text { development }\end{array}$ \\
\hline $\begin{array}{l}\text { Main funding } \\
\text { bodies }\end{array}$ & $\begin{array}{l}\text { HEFCE; VC funds (some } \\
\text { government); income } \\
\text { earned }\end{array}$ & $\begin{array}{l}\text { Industrial funding; some } \\
\text { research council funds }\end{array}$ & $\begin{array}{l}\text { European Union funding; } \\
\text { RDA funding }\end{array}$ \\
\hline $\begin{array}{l}\text { Features of } \\
\text { funding/ } \\
\text { activity }\end{array}$ & $\begin{array}{l}\text { Licensing and spin-out } \\
\text { activity; some funds } \\
\text { support start-up } \\
\text { companies }\end{array}$ & $\begin{array}{l}\text { Mainly funded by industry or } \\
\text { though Research Council } \\
\text { schemes for training or } \\
\text { collaborative research }\end{array}$ & $\begin{array}{l}\text { Generally targets SMEs; } \\
\text { EU funding has strict } \\
\text { targets with respect to, eg, } \\
\text { job safeguarding and } \\
\text { creation and company } \\
\text { turnover }\end{array}$ \\
\hline $\begin{array}{l}\text { Items } \\
\text { elucidated from } \\
\text { HEIF } 4 \text { strategy } \\
\text { documents }\end{array}$ & $\begin{array}{l}\text { Spin-outs/incubation; } \\
\text { HEIF } 4 \text { budget for } \\
\text { spin-outs/incubation; } \\
\text { HEIF } 4 \text { budget - patents; } \\
\text { Invention } \\
\text { disclosures/opportunity ID; } \\
\text { Patents; } \\
\text { Licensing; } \\
\text { Income from } \\
\text { IP/commercialization; } \\
\text { IP/commercialization } \\
\text { mentioned; } \\
\text { Proof-of-concept funds (as } \\
\text { \% of total HEIF4); } \\
\text { Incentive policy for } \\
\text { academics to engage; } \\
\text { Academic staff as } \\
\text { Enterprise Champions; } \\
\text { Academic staff training in } \\
\text { enterprise; } \\
\text { Spin-ins }\end{array}$ & $\begin{array}{l}\text { Strategic Relationships with } \\
\text { large companies; } \\
\text { Support for academic staff to } \\
\text { engage in KT activities; } \\
\text { National/international focus; } \\
\text { Collaborative/contract } \\
\text { research; } \\
\text { Consultancy/commercial } \\
\text { services; } \\
\text { Master's and doctoral level } \\
\text { programmes for industry; } \\
\text { Non-credit-bearing } \\
\text { courses/CPD; } \\
\text { CASE studentships; } \\
\text { Academic staff training in KT; } \\
\text { Secondments to/from } \\
\text { industry; } \\
\text { KTP; } \\
\text { Enterprise clubs/support to } \\
\text { start-ups (from outside HEls); } \\
\text { UK KT networks; } \\
\text { Student placements }\end{array}$ & $\begin{array}{l}\text { Regeneration } \\
\text { (income/involvement); } \\
\text { SME income } \\
\text { SMEs assisted; } \\
\text { Sales increases; } \\
\text { Jobs created/safeguarded; } \\
\text { Graduate } \\
\text { retention/employment/ } \\
\text { employability/employer } \\
\text { engagement; } \\
\text { Community/social } \\
\text { engagement; } \\
\text { Public sector; } \\
\text { Regional focus; } \\
\text { Growth in KT income; } \\
\text { Companies created or } \\
\text { attracted to region; } \\
\text { Student/graduate } \\
\text { start-ups; } \\
\text { Student enterprise }\end{array}$ \\
\hline
\end{tabular}

Source: HEIF 4 strategies from http://www.ikt.org.uk/, accessed April 2009; The European Regional

Development Fund - an Introductory Guide, Office of the Deputy Prime Minister, London, 2001.

However, the amount of funding available is dependent on the level of identified economic deprivation in subregional areas. In the North West Region of England the economy has been described as underperforming: the North West Development Agency's Regional Economic Strategy states:

'Gross Value Added (GVA or output) per head is $12 \%$ lower than the England average, resulting in an output gap of $£ 13$ billion. $£ 3$ billion of this is due to fewer people working per head of population and $£ 10$ billion is due to lower productivity (GVA per employee).' (NWDA RES, 2006, p 3)

In contrast, as measured by GVA per head, the South East of England '. . . is currently the second most prosperous region in the UK behind London'. It was also '. . . over the period $1997-2003$. . . the fastest growing region in the UK'. It is 'in national terms, a highly prosperous region' (SEEDA, 2006).

The resulting difference in levels of economic development funding has led to disparate experiences in different regions of the UK and, in the context of this paper, very different responses from universities. An unusual feature of university economic development work is that the links between industry, government and the university are via a funding model that sees government at regional or European level providing funding directly to the university. This funding requires the university to meet targets associated with the support of small to medium sized enterprises (SMEs). Within de minimis regulations, ${ }^{2}$ this support is often free of charge for the SMEs involved. This study compares these two regions of the UK, the North West and the South East of England, which attract very different levels of economic development funding as a 
result of the difference in economic performance and examines the effects of this difference.

\section{The topic - state of the art}

University economic development activities are, in the view of the authors, a subset of the overall KT activity of a university. They do not include the additional economic benefits to a region resulting from the presence of a university such as general university or student spending or jobs at the university. Previous work by the authors has classified university KT activities into three categories: technology transfer, business support and regeneration (economic development). These categories are outlined further in Table 1 and the rationale for this taxonomy has been outlined elsewhere (Decter et al, 2010). In this brief review, literature relating to UK KT is examined. Although this embraces more than just university economic development activity it is reflective of the current state of the UK literature on KT. There have been very few UK academic papers that solely explore university KT activity as it relates to economic development. Those that have been identified are discussed below.

A recent review of research on the effectiveness of technology transfer concludes that '.. much of it has been descriptive and approached from the perspective of inventorying the phenomenon' (Phan and Siegel, 2006, $\mathrm{p} 44)$. The UK academic literature relating to direct KT from universities is relatively sparse and often uses descriptive methodologies and/or analysis of survey results. Theory-based publications are relatively rare in this field (Chell and Oakey, 2005; Phan and Siegel, 2006; Nicolaou and Birley, 2003; Rothaermel et al, 2007). There also appears to be little use of theory brought to bear on the choices made by individual universities in terms of KT work. Phan and Siegel suggest that 'the use of institutional theory and evolutionary economics perspectives to explain the persistence of differences in effectiveness across regions may be a fruitful direction in which to take the research related to regional development and university technology transfer' (Phan and Siegel, 2006, p 44). Previous work by the present authors has used evolutionary theory to examine influences on universities, including the Research Assessment Exercise (RAE) which reinforced a preference for pure, rather than applied, research (Decter, 2009); and the range and levels of UK university KT activities (Decter et al, 2010).

The UK KT literature has a focus on entrepreneurship, particularly spin-out company formation, amongst academics. For example Franklin et al examine the role of surrogate (or external) entrepreneurs in university spin-out companies (Franklin et al, 2001). Lockett and Wright explore '. . the extent to which the capabilities of technology transfer offices are important influences on the generation of university spin-outs within the context of universities' resources and environments' (Lockett and Wright, 2005, p 1044). Government reports look for trends and classifications of university types which are unrelated, and possibly irrelevant, to university knowledge transfer behaviour. This study seeks to understand more clearly the influences that affect decisions to undertake particular types of KT activity relating to regeneration.

There is little evidence of published research which examines KT at individual universities and the impact of KT on regional regeneration. Benneworth and Charles do examine university spin-off companies and their effects on the economic development of regions, comparing Newcastle in the UK with Twente in the Netherlands. This work focuses on university spin-offs rather than indigenous companies, however, and recognizes that these companies may not remain within the region (Benneworth and Charles, 2005).

Exploring a regional perspective on economic development issues similar to the one undertaken here, Huggins and Johnston examine the '. . . differences in the relative contribution of HEIs across regions' (Huggins and Johnston, 2009, p 1088). They develop '... a range of measures by which to analyse differences in the value added and labour productivity of universities at an institutional and regional level, as well as their knowledge commercialization capabilities' (Huggins and Johnston, 2009, p 1089). Universities are classified by Huggins and Johnston according to whether they are 'pre-1992' or 'post-1992' (in 1992 polytechnics were given university status - thus 'post-1992' includes the former polytechnics). Unfortunately this simple categorization fails to recognize the pre-1992 institutions which also have roots in providing technical support to industry. Regions of the UK are also categorized simply as either 'competitive' or 'uncompetitive'. The 'regional economic relevance of HEIs' is calculated through '. . the value added generated by institutions as a proportion of the total value added generated across regions as a whole' (Huggins and Johnston, 2009, p 1093). Because the study takes account of data for one academic year only, that is 2005-06, it does not measure any changes within these regions: as a result, the increasing involvement of many universities has been omitted. The authors admit that their approach is 'rather binary in nature' and suggest that the true picture is more complex (Huggins and Johnston, 2009, p 1100). We address some of this complexity in this study. 
Because the UK literature on knowledge transfer is still rather limited in volume, there are actually many gaps in this body of work. Some of these have been filled in the American literature, but only with reference to that country. It has been pointed out that '. . .the contrasting historical evolution of the modern university systems of the United States and the nations of Europe means that the conclusions of studies of universityindustry research interactions and technology transfer in the United States may not apply to the European context' (Geuna and Mowery, 2007, p 68). The heterogeneity of UK university KT activity has been mentioned by several researchers, but they have not dealt with the reasons for these differences in approach in any meaningful way (Meyer and Tang, 2007; Chapple et al, 2005; Geuna and Mowery, 2007). The variety of KT activities undertaken by universities has been noted in this research and is outlined in Table 1.

An extensive literature search has shown no evidence of the use of an evolutionary theory approach to UK knowledge transfer from universities (other than that of the present authors). The influences on individual UK universities to engage in regional economic development activities have not been explored. In this study, evolutionary theory is used as a framework for analysis of UK university regional regeneration activities.

\section{Evolutionary theory and the development of university knowledge transfer}

Evolutionary theory in economics analyses the rationale for and outcomes of the actions of firms. Nelson and Winter detail the adaptation of the features of Darwin's evolutionary theory into a tool in the field of economics (Nelson and Winter, 1982). Evolutionary theory likens the economic system to a biological one. It uses the mechanisms outlined in Darwinian theories of evolution to describe economic phenomena which previously had not fitted well with more traditional economic treatments. Here, the tenets of evolutionary theory are used to explore UK universities and their engagement in regeneration activities. Evolutionary theory is useful because it accommodates discussion of how an organization comes to behave in a particular way. In other words, we can analyse the evolution of the organization in the face of external factors and the historical influences that shape an organization's behaviour. Also, the ideas of path dependence and creation are useful concepts in exploring the responses of universities in the context of economic development.

The development of routines in organizations and the concept of search, akin to mutation in Darwin's theory of evolution, are the key elements of evolutionary theory used in this study (Nelson and Winter, 1982;
Nooteboom, 1997; Nelson, 2006). The development of routines can be useful to organizations: according to Hodgson (1998, p 416), 'Routines in the firm have a relatively durable quality through time. They may help to retain skills and knowledge, and to some extent they have the capacity to replicate through imitation, personal mobility, takeovers, and so on'. However, routines can also prevent organizations from changing. 'Survival requires a balance of, on one hand, routine, habit, conservatism, continuity, and on the other hand, adaptability, innovation, shift' (Nooteboom, 1997, pp 63-64). Routines can act as a kind of organizational memory enabling efficient operation, but they can also restrict the ability of an organization to adapt and innovate (Hodgson, 1998; Nooteboom, 1997).

The manner in which KT activities have developed at universities is of interest. Garud and Karnøe (2001, p 2) '... offer a contrasting perspective that we term path creation. In our view, entrepreneurs meaningfully navigate a flow of events even as they constitute them'. In this perspective the decision to engage in regeneration activities, which is quite different to normal university routines, is taken deliberately in order to create a new direction for the university.

The influence of the UK's Research Assessment Exercise (RAE) may have unintentionally produced a path-dependent response: this has been discussed in previous work (Decter et al, 2010). Although established to allow for selective research funding, the RAE appears to have a wider effect on universities. Antonelli (1997) states, 'The trajectory of a pathdependent process however cannot be fully anticipated on the basis of the original events'. In universities these concepts can be applied to the continuation on or deviation from a specific path involving particular forms of knowledge transfer - in this analysis, regional regeneration activities.

Hodgson discusses the selection of maximizing behaviours and the likelihood that the objectives of firms differ in this respect. 'With a multiplicity of adaptive peaks the path followed and thus the peak obtained is path-dependent: a result of history' (Hodgson, 1998, p 422). The ' . . . twin propositions from evolutionary theory of persistence and differences in firms' activities' are examined in Helfat's study. Persistence is related to ideas of path dependence (Helfat, 1994, p 1721). In the context of university KT in the UK, over the last decade there has been a multitude of funding opportunities and a wide range of resulting KT patterns developed at different universities (Decter et al, 2010). This is a similar proposition to the ideas expressed above relating to adaptive peaks and perhaps akin to the early stages of new growth in regions described by Kenney and von Burg: 
'Both economists dealing with innovations and industrial geographers studying regional industrial growth find that often there is an initial period of openness with a number of contenders prior to the selection of a dominant design or dominant location. It is at such moments that the small events can result in the long-term differences.' (Kenney and von Burg, 2001, p 130)

It is too early in the development of KT at UK universities to say definitively which, if any, of these patterns will be enduring ones. Many UK universities are dependent on external funding for KT activities to continue. In UK University KT terms, regional regeneration activities are one of a range of $\mathrm{KT}$ contenders currently being explored by some universities. It may be that a dominant design in UK university KT will emerge, but this has yet to happen. It remains to be seen whether or not regeneration activities will become dominant in some regions in the future.

\section{Research focus}

In this study two regions of the UK are compared, the North West and the South East of England, which attract very different levels of economic development funding. The effects of this difference are examined. For example, in the North West of England the European Regional Development Fund (ERDF) has had £1,076 M available for projects in the region for the period 2000-06 for Objective 1 and 2 areas. In the South East of England, however, the amount was $£ 23 \mathrm{M}$ for the same period.

Factors which influence UK universities to engage with economic development activities are considered. It would be simple to assume that universities become involved in regeneration as a response to available funding. By examining universities in two regions of the $\mathrm{UK}$, with very different levels of funding, it is possible to explore the effect of funding. In order to do this the relative levels of regeneration activities, and funding, must be established for universities in the North West and South East regions of England. Figure 1 shows the aggregates of various types of regeneration funding for the six academic years 2002-03 to 2007-08.

In all cases the level of funding is higher in the North West region than in the South East, although there is substantial variation depending on the funding body. When regarded as total regeneration funding, though, the ratio is approximately 5.5:1 (NW:SE). Although the inclination to engage in regeneration activities might be for reasons beyond those solely to do with funding, it is likely that the level of funding will affect the ability to undertake such activities. While external funding is

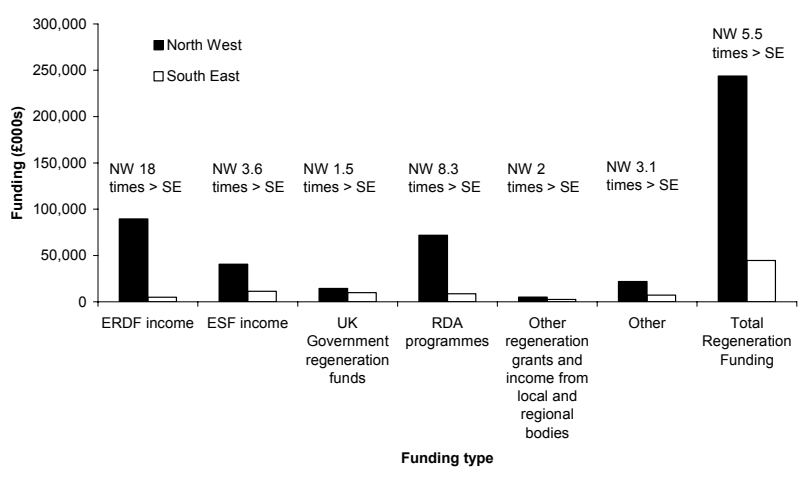

Figure 1. Regeneration funding aggregate for academic years 2002-03 to 2007-08.

Source: HEBCI Surveys (HEFCE, 2006; HEFCE, 2007; HEFCE, 2008; HEFCE, 2009).

important to maintain university engagement in economic development, other factors influence the decision to embark on regional regeneration projects.

\section{Methodology}

Quantitative data from the UK government's Higher Education Business and Community Interaction (HEBCI) Survey have been used to track economic development activity from universities in the two UK regions. Figures 1, 5 and 6 illustrate this approach. To develop Figure 1, HEBCI data relating to regeneration funding were aggregated from surveys for the years 2002-03 through 2007-08 (HEFCE, 2006; HEFCE, 2007; HEFCE, 2008; HEFCE, 2009). Figures 5 and 6 show the total numbers of SME contracts in the local Regional Development Agency (RDA) area. These figures are the sum of consultancy, contract research and facilities and equipment contracts for the six academic years 2003-04 to 2008-09. This second set of data covers a period one year later than the first due to the changes in availability of data in the HEBCI surveys for 2002-03 and 2008-09. HEBCI data have also been used to construct Figures 7-13 which illustrate the KT funding received by universities that have been selected for further study: these are discussed in detail in later sections.

This analysis of the levels of regeneration activity provided a basis for selection of universities for study. From this initial analysis 12 universities, five in the North West and seven in the South East, have been identified as potentially engaging in regeneration activities (see Table 2). It is not possible, using the available data, to ascertain whether a contract with an SME in the region has been undertaken as part of a government funded regeneration programme. For example such contracts may be undertaken with 
Table 2. North West and South East universities potentially engaged in regeneration.

\section{North West}

University of Central Lancashire* (UCLAN)

Lancaster University*

University of Liverpool

Liverpool John Moores University

University of Salford*

\section{South East}

University of Brighton*

Buckinghamshire New University*

University of Oxford

University of Portsmouth*

University of Reading

University of Southampton*

University of Surrey

*These universities have been studied in detail (see Table 3).

well-funded small businesses that pay the university directly for services: in such cases the contract is more likely to be part of a business support programme. These differences are discussed later in this paper.

To determine the likely provenance of SME contracts, qualitative data were analysed. Strategy documents prepared in the form of answers to a set of questions by each university in compliance with the fourth round of the UK government Higher Education Innovation Fund (HEIF) were used in two ways (HEFCE, 2008a). First, a large number of strategy documents was analysed to develop models and definitions of different types of KT activities undertaken by UK universities. Second, individual strategies were analysed to determine whether regeneration activities are undertaken with a view to regional regeneration or whether SME contracts are undertaken due to other motivations.

For the latter analysis, HEIF 4 strategies were analysed using Wmatrix, a data-driven software tool for linguistic analysis through corpus comparison. The Wmatrix results have been used to support interpretation of HEIF 4 strategies and allow the researcher to check the context of significant words to ensure that interpretations are correctly assigned (Rayson, 2003). ${ }^{3}$ Initially 'key word cloud' diagrams for each of the strategy documents were examined to seek evidence of regeneration/economic development 'buzz' words. ${ }^{4}$ These words were then checked with regard to the context in the main body of the text to ensure correct interpretation. Buzz words were not used as a substitute for reading the text, but rather as a helpful indicator.

Without corroborating quantitative evidence it is difficult to distinguish strategies that accurately describe a university's commitment to a particular course of action from those that merely espouse the jargon and rhetoric of the day. For this reason interviews were carried out and quantitative data relating to funding patterns and SME contracts were also analysed.
Using this method, the Universities of Brighton, Buckinghamshire, Portsmouth and Southampton appeared to have the strongest regeneration focus in the South East. In the North West region all five of the universities listed in Table 1 had some focus on regeneration; but, using the method described above, this focus was found to be strongest at UCLAN and the Universities of Lancaster and Salford. Further discussion will focus on these seven universities, as highlighted in Table 2. HEIF 4 strategies for these universities are examined in more detail to provide perspectives on their approaches to KT activity. In addition, other relevant data acquired from interviews, university websites and the Higher Education Statistics Agency (HESA) are discussed.

A case study of one regeneration programme, developed at Lancaster University using research findings, has been included to provide further insight into regeneration activities. Named 'Leading Enterprise and Development' (LEAD), the programme aims to contribute to raising regional productivity, competitiveness and skills by addressing issues of leadership within the context of the SME sector generally and in particular in the owner-manager's business. The case study has been included both to illustrate a successful university regeneration programme and because the approach has enabled one university department to embrace KT activity as an equal part of its overall activities alongside research and teaching. Both the path creation involved and the ability of that department to absorb KT activity as part of its 'routine activity' are of interest here.

\section{Findings}

\section{Definitions and models of UK KT activity}

Regeneration activity in the UK has been described as being typically characterized by engagement with Regional SMEs (Decter et al, 2010). HEIF 4 strategies have been used to determine the full range of KT activities undertaken in English universities. A spreadsheet of university KT activities was developed through analysis of 39 of the 133 HEIF strategies published: the KT activities discussed in the strategy documents were listed in the spreadsheet for each of the universities. Most of these activities were common to more than one university and they appeared to fall into three broad categories, as perceived by Decter et al. These categories have been defined as technology transfer, business support and regeneration.

Table 1 shows a summary of this extended categorization including funding, features and a list of the types of activities that would fall into each category. The following paragraphs and Table 1 provide a 
definition of each of the three categories; technology transfer, business support and regeneration.

Business support is closest to 'normal' academic pursuits because it involves research funded wholly or partially by industry or teaching to industry participants. The normal routines of universities are research and teaching, so business support activities are an extension of these and therefore relatively easily undertaken by many universities. In evolutionary theory terms this is a path-dependent approach to university KT.

Technology transfer involves a move away from normal routines towards a more commercial outlook, either through the university's own motivations or encouraged by funding streams. From an evolutionary theory perspective, UK universities that have been involved in technology transfer, prior to the advent of KT funding in the late 1990s, have unusual 'routines'. They have followed a different path, perhaps because these universities retained routines established in their early history, which involved a strong connection to industry, or because of a deliberate departure (that is, path creation).

Regeneration/economic development activities can indicate the influence of European and regional development agency funding. These activities are quite clearly a long way from the normal routines of UK universities and indicate elements of deliberate path creation (see Table 1 for examples). In the main, activities involve working with small companies in the local region, a major departure from expected routines of research and teaching.

It should be noted that economic benefits may accrue from any of these three types of KT activities. However, those labelled here (Table 1) as regeneration activities are funded and undertaken with the purpose of promoting economic development within a specific region or sub-region. In addition they are the types of university KT activities that are most likely to succeed in this purpose because they direct resources to SMEs already based in the disadvantaged region. Technology transfer activities, for example, are more likely to be targeted at companies licensing technology from outside the region or indeed country, or spin-out companies that may exit through a trade sale or move to a more prosperous region.

Figures 2-4 illustrate the relationships between KT categories at UK universities with different KT landscapes. Figure 2 illustrates a scenario in which the university focuses solely on pure research and teaching and KT activities may exist but are not embedded in the university. This represents what might be expected of a

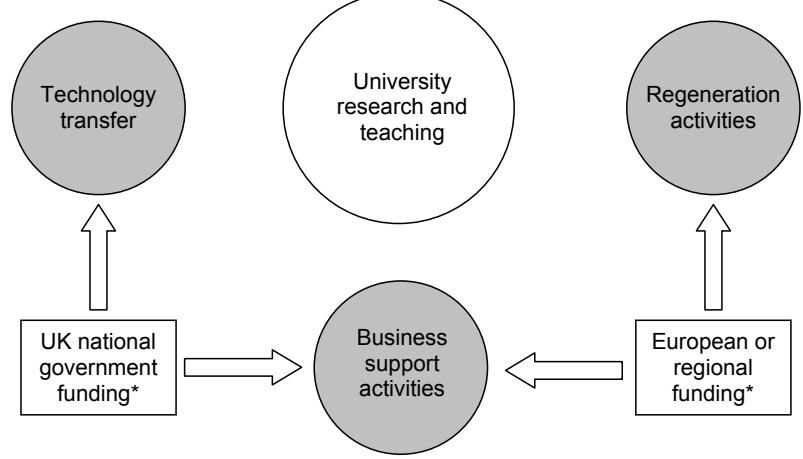

Figure 2. Knowledge transfer activity - low level of university engagement.

Note: * External motivations (for example, funding).

university fully conforming to established university routines in the UK: that is, a strong emphasis on research and teaching with KT activities undertaken solely due to external funding and government pressure. In Figure 3, business support activities are depicted as embedded as routine and there is some intrinsic motivation to undertake technology transfer, but regeneration activities are undertaken as one-off projects and do not form part of 'business as usual'. In this case one might theorize that the university undertakes business support naturally as a result of its history, either due to a lack of research funding from government sources, or due to continuing long-term links with industry. A long, uninterrupted history of industry links would allow the university to adopt a stance in which the pursuit of pure research and maintaining what have always been considered appropriate associations with industry can co-exist. A reduction in research funding from government, such as that experienced by some universities after the first

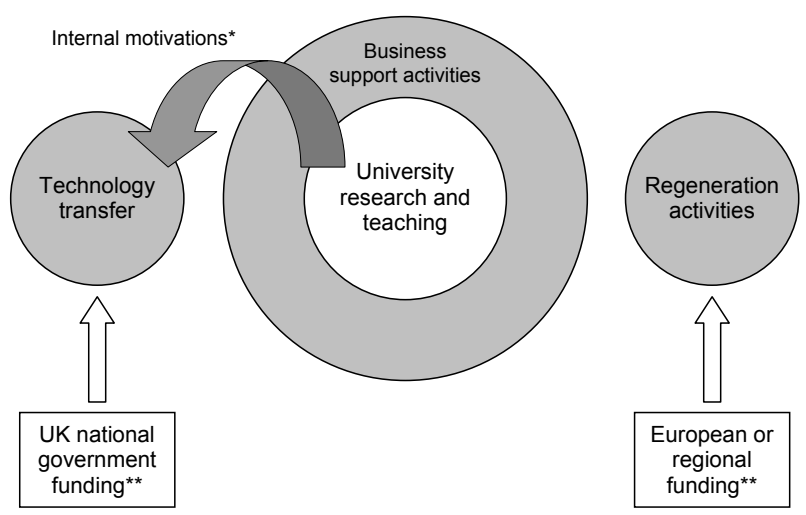

Figure 3. Knowledge transfer activity - business support embedded.

Notes: * From university history or individual academics;

** External motivations (for example, funding). 

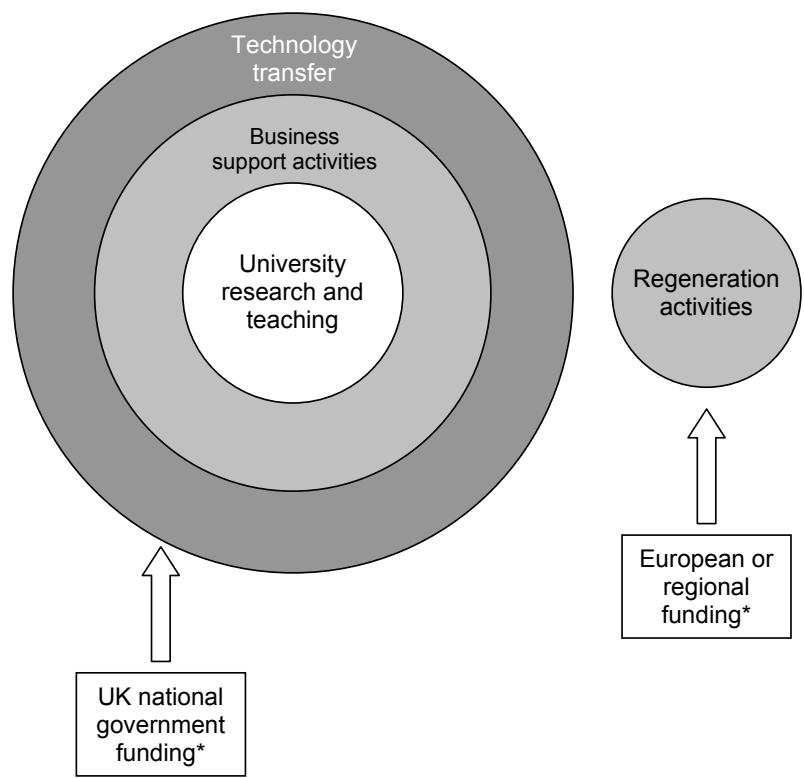

Figure 4. Knowledge transfer activity - business support and technology transfer embedded.

Note: * External motivations (for example, funding).

RAE, may lead to a university turning to industry to maintain levels of research activity. The University of Surrey has taken this approach (see Interviews, University of Surrey, 2008). Some intrinsic motivation to carry out technology transfer might also be expected to emerge from existing connections with industry.

In the third scenario (Figure 4) both business support and technology transfer are normal parts of university business. In these universities norms of behaviour include not only research for and teaching to industry but also an acceptance of a 'legitimacy' in licensing technologies and spinning-out companies. This culture might arise due to early successes in these areas leading to enhanced university funding, rejection of the prevailing culture in UK universities or the belief that such activities might co-exist with, or even enhance, pure research.

One might speculate on a situation in which regeneration activities become embedded as routine in universities. However if the variation in levels of regeneration activity correlate with levels of external funding this model is unlikely to be appropriate. Data examined in the following section may shed some light on this area. There has been some speculation in the literature as to which types of universities might embrace different types of KT activities (Shattock, 2009; Holi et al, 2007). This will be examined taking into account age, size and types of university as well the effects of regional location and funding.

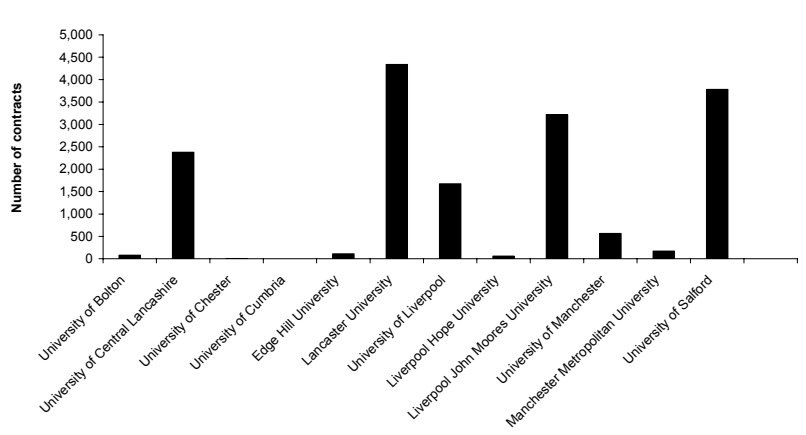

Figure 5. Total number of contracts with SMEs in NW RDA area, 2003-04 and 2008-09.

Source: HEBCI Surveys (HEFCE, 2006; HEFCE, 2007; HEFCE, 2008; HEFCE, 2009, HEFCE, 2010).

\section{SME engagement}

Figures 5 and 6 show the total aggregated number of contracts with SMEs within the areas of the RDAs for the North West and South East. With the exception of Buckinghamshire New University there is a much lower level of engagement with regional SMEs in the South East compared to the North West. However, if the ratio of regeneration funding - North West-to-South East - is applied to the level of SME contracts, then some of the South East universities might also be considered to be engaged. In the North West region the Universities of Central Lancashire, Lancaster, Liverpool, Liverpool John Moores and Salford were strongly engaged with SMEs in the region in the period 2003-04 to 2008-09. Taking a value of 1,500 contracts as an arbitrary cut-off point ( 250 contracts per year) we can divide this value by 5.5 , the ratio of total regeneration funding in the two regions: a cut-off value of approximately 270 contracts in the South East region can then be justified as accounting for the lower levels of regeneration funding in the South East. Using this reasoning, the Universities of Brighton, Buckinghamshire, Oxford, Portsmouth,

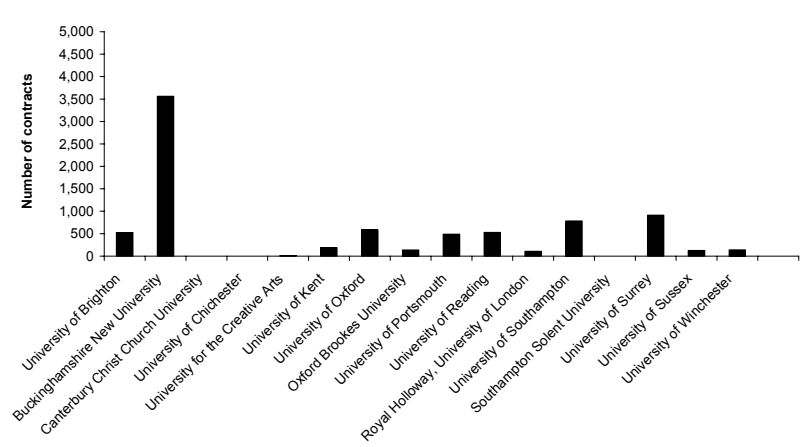

Figure 6. Total number of contracts with SMEs in SE RDA area, 2003-04 and 2008-09.

Source: HEBCI Surveys (HEFCE, 2006; HEFCE, 2007; HEFCE, 2008; HEFCE, 2009, HEFCE, 2010). 
Table 3. Variables relating to selected universities.

\begin{tabular}{|c|c|c|c|c|c|c|}
\hline University & $\begin{array}{l}\text { Total income } \\
(£ M) \\
2007-08^{a}\end{array}$ & $\begin{array}{l}\text { Year KT/TT } \\
\text { office opened }^{b}\end{array}$ & $\begin{array}{l}\text { Number of } \\
\text { PhDs }^{c}\end{array}$ & $\begin{array}{l}\text { RAE ranking } \\
(2008)^{d}\end{array}$ & University type ${ }^{a}$ & $\begin{array}{l}\text { ERDF funding } \\
\text { available in region } \\
\text { ( } £ \text { million) }\end{array}$ \\
\hline $\begin{array}{l}\text { Lancaster } \\
\text { University }\end{array}$ & 163 & 2000 & 215 & 20 & New (1960s) & 1,076 \\
\hline $\begin{array}{l}\text { University of } \\
\text { Brighton }\end{array}$ & 146 & 1996 & 45 & 59 & $\begin{array}{l}1992 \text { (former } \\
\text { polytechnic) }\end{array}$ & 23 \\
\hline $\begin{array}{l}\text { Buckinghamshire } \\
\text { New University }\end{array}$ & 55 & 2001 & 5 & 119 & $\begin{array}{l}\text { Former university } \\
\text { college }\end{array}$ & 23 \\
\hline
\end{tabular}

Sources: " Individual university websites for Annual Reports and background information; ${ }^{b}$ HEFCE (2008), Higher Education-Business and Community Interaction Survey 2006-07 July 2008/22 and HEFCE (2007) Higher Education-Business and Community Interaction Survey 2004-05 and 2005-06 July 2007/17; ' HESA statistics Table R1 Share of research output per share of research input, weighted by cost centre 2006/07, http://www.hesa.ac.uk/, accessed June 2009; ${ }^{\mathrm{d} T H E S}$ interpretation, http://www.timeshighereducation.co.uk/ Journals/THE/THE/18_December_2008/attachments/RAE_2008_THE_RESULTS.pdf, accessed December 2008; ${ }^{e} E R D F$ (amount available 2000-06 Objectives 1 and 2), The European Regional Development Fund - an Introductory Guide, Office of the Deputy Prime Minister, London, 2001. *College of Advanced Technology.

Reading, Southampton and Surrey were felt to be of interest. Using the method described above, with regeneration buzz words being used to explore HEIF strategies, the Universities of Brighton,

Buckinghamshire, Portsmouth and Southampton were then identified as having the strongest regeneration focus in the South East. In the North West this focus was strongest at UCLAN and the Universities of Lancaster and Salford.

Table 3 outlines various indicators relating to these seven universities. Because these universities represent a very diverse group with regard to university type, research quality or quantity, based on RAE performance and $\mathrm{PhDs}$ produced, or size, based on income, it seems unlikely that these factors influence regeneration engagement. It is not possible to correlate regeneration activities with these more customary university classification methods, although recent reports have attempted to do so (Hewitt-Dundas, 2010; Sainsbury, 2007). It is argued here that it is more useful to classify universities more directly in terms of their KT engagement profile (see Decter et al, 2010).

The availability of regeneration funding does relate to some extent to the level of activity, as already discussed. Perhaps also of interest is the date of opening of the KT office at some, but not all, of these universities, which coincides with the earliest calls for funding bids in the late 1990s.

\section{Funding history and KT strategy}

The timing of regeneration funding in relation to other $\mathrm{KT}$ funding received may have an influence on regeneration engagement. Figures $7-13$ show approximate chronological funding patterns for the seven universities being examined (HEFCE, 2006; HEFCE, 2007; HEFCE, 2008; HEFCE, 2009; HEFCE,

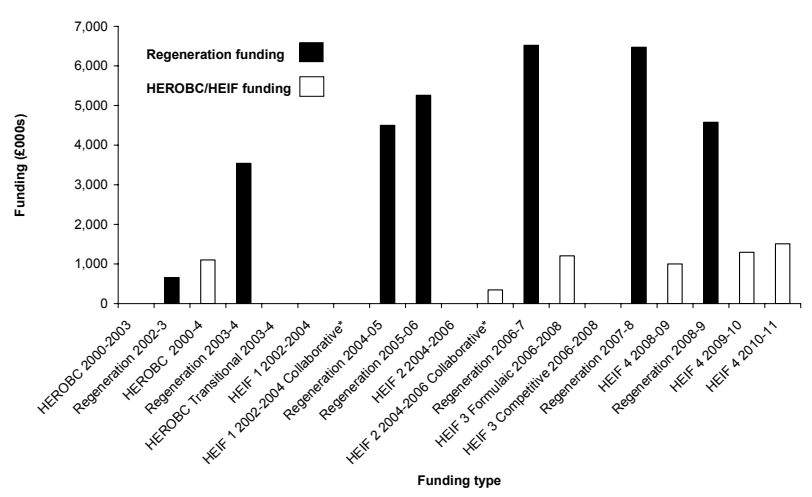

Figure 7. KT funding pattern for University of Central Lancashire, KT office established 1999. 


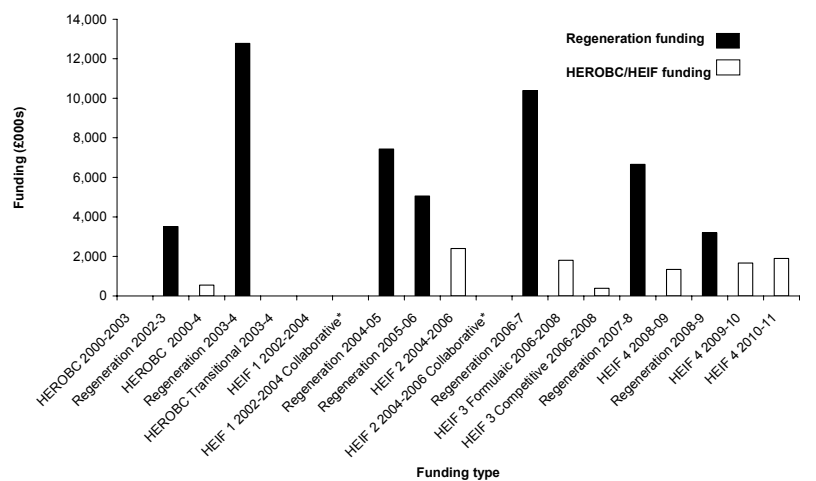

Figure 8. KT funding pattern for Lancaster University, KT office established 2000.

2010). For the three North West Universities identified as engaging in regeneration, UCLAN, Lancaster and Salford, it is clear that much of the KT funding received has been regeneration funding; that the amounts have been very large; and that this started early in their KT funding history. This may be due either to decisions taken as to the direction of the university KT programme or more directly due to the influence of

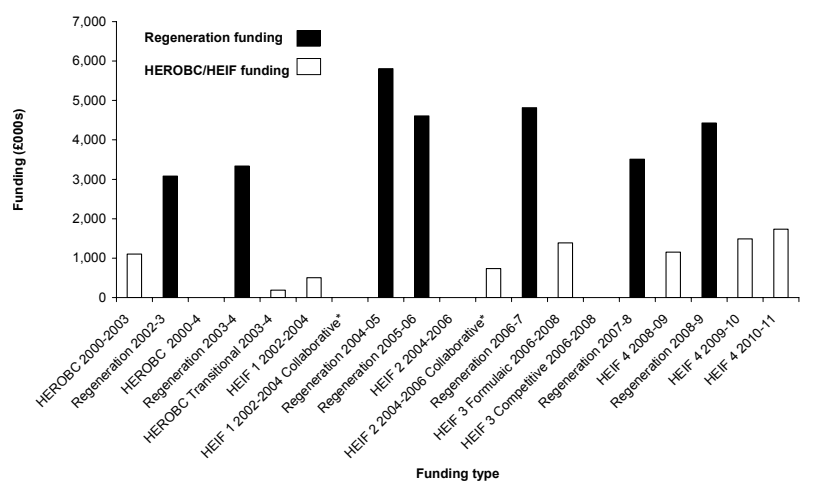

Figure 9. KT funding pattern for University of Salford, KT office established 1999.

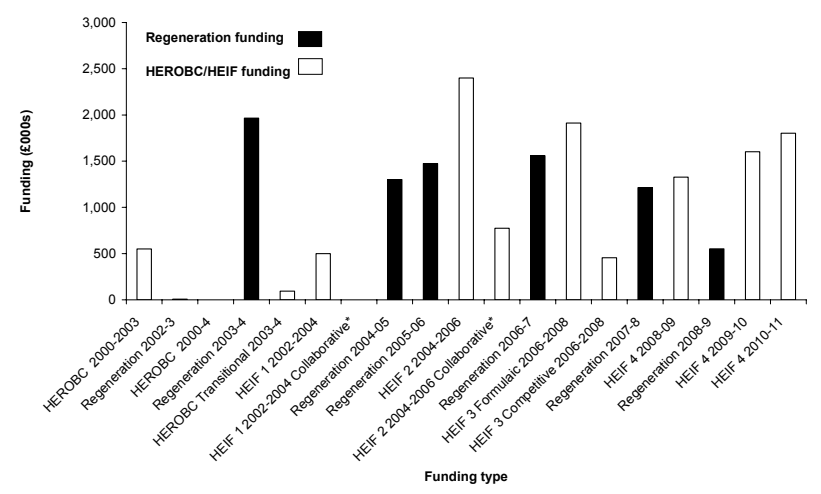

Figure 10. KT funding pattern for University of Brighton, KT office established 1996.

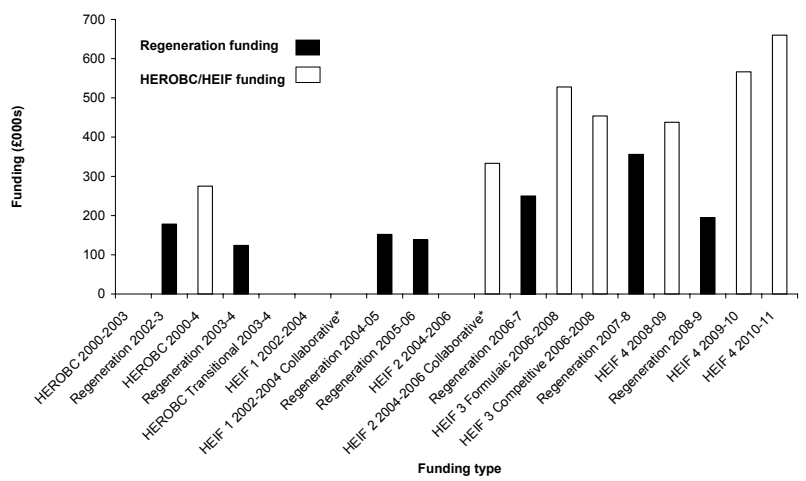

Figure 11. KT funding pattern for Buckinghamshire New University, KT office established 2001.

receiving funding. These three universities all state that their current KT offices opened in 1999 or 2000 when applications for such funding began - although the University of Salford had other, more commercial interests prior to this date. Lancaster University specifically employed staff with experience in European regeneration funding (see Interviews, Lancaster University, 2009).

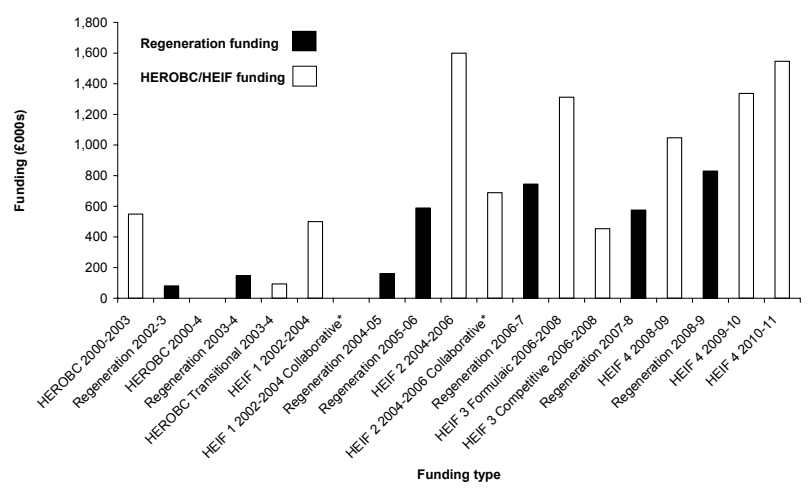

Figure 12. KT funding pattern for University of Portsmouth, KT office established 1997.

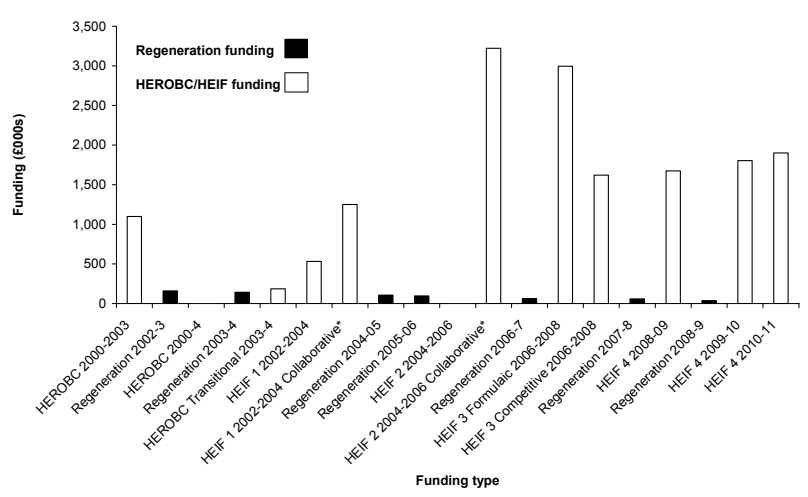

Figure 13. KT funding pattern for University of Southampton, KT office established 1992. 
The focus at the University of Salford is on 'academic enterprise' which is the name given to their approach: 'a unique, a different view of how a university should relate to business in the community'. It is also referred to as '. . . socially inclusive regeneration' (Interviews, University of Salford, 2007).

At UCLAN there is a strong regional, public sector focus and it has been very active in both work with SMEs and graduate enterprise. There is a clear influence of policy here:

'Externally, clearly we've been influenced enormously by the policies coming out of Europe to support small businesses, to support innovation, to support that kind of knowledge based economy.' (Interviews, UCLAN, 2010)

All three of these universities make strong statements about regeneration in their HEIF 4 strategies, as the following quotes illustrate.

'Our KT activity will therefore make a significant contribution to the region's economic and social development.' (HEIF 4, UCLAN, 2008)

'Support the Regional Economic Strategy in order to maximise both our programme opportunities and funding to achieve them. Therefore the KPIs in Table 1 all match to RES priorities.' (HEIF 4, Lancaster, 2008)

'The main focus of our delivery will be local and regional, supporting RDA and sub-regional strategies, but with global reach.' (HEIF 4, Salford, 2008)

It is possible that these early regeneration funding successes have helped to shape the views at these three universities towards regeneration activities as routine. This inclination is perhaps surprising given the vulnerability of these activities due to the reliance on government funding. Alternatively, funding applications may have followed a conscious decision on the part of universities to participate in regional engagement, indicating path creation.

In contrast, regeneration funding patterns at universities in the South East of England are more variable. Overall, as previously noted, funding levels are much lower. The University of Brighton received significant regeneration funding in 2003-04 prior to any large amounts of less targeted KT funding. The university appears to have made a deliberate decision to engage with its region.
'The other thing that was important about it was that it helped us build relationships within region. In the very early days we basically said we want to be the local university, we want to be your local university and I think nothing has deterred us from that.' (Interviews, University of Brighton, 2009.)

Its HEIF 4 strategy states:

'To meet this goal we must become a force in our regional economy which requires this activity to be prominent in our portfolio - unequivocally part of its 'core business' with Research and Teaching.' (HEIF 4, Brighton, 2008)

This highlights not only the engagement of University of Brighton with the regeneration agenda but also the intention to adopt such work as equal to the more usual university activities of research and teaching. The statement presents a clear picture of path creation with the University of Brighton purposefully setting out a new direction for its future. 'Such a process of mindful deviation lies at the heart of path creation' (Garud and Karnøe, 2001, p 6).

Buckinghamshire New University presents a much less clear picture. High levels of SME contracts are reported, but KT funding, both for regeneration activities and more generally, has been relatively sparse. Strategy statements in the HEIF 4 plan related to regional activity and to business, indicating that the involvement with SMEs is possibly through a 'Business Support' model:

'In short the knowledge transfer strategy will enable the university to fulfil its mission to become business facing, focusing mainly but not exclusively on the public and private business communities in Buckinghamshire and surrounding areas.' (HEIF 4, Buckinghamshire New, 2008)

The word 'regeneration' does not appear in the HEIF 4 strategy for Buckinghamshire New University and 'economic development' appears only once, which supports the view that these activities with SMEs relate more to business support than regeneration.

Although in receipt of little regeneration funding, the University of Portsmouth makes strong statements about regeneration in its HEIF 4 strategy document. For example, included as one of the four headline aims of the University of Portsmouth's Strategic Plan 2007-12 is this: 
'To contribute to sustainable economic, social, cultural and community regeneration and development.' (HEIF 4, Portsmouth, 2008)

In addition, both of the 'flagship projects' outlined in the HEIF 4 strategy document relate to the economic development of the region. The University of Portsmouth website includes a large section on 'Economic Impact' of the university on its region, which opens with the words:

'The University of Portsmouth has a long tradition of helping UK business succeed and in the process enabling those businesses to create new jobs, wealth and prosperity for all.'

It also states, later, that:

'The University is committed to the renaissance of Portsmouth and the wider region and has worked ... to support enterprise led regeneration.' (University of Portsmouth, 2010)

The university presents itself as engaged with regeneration and its region.

The University of Southampton has received little regeneration funding and has a good reputation for technology transfer activities. Strategy statements reinforce this but also describe strong relationships with SMEs. This is expressed in terms of SME income, albeit with the implication of a stronger focus on paid business support activities than on government sponsored regeneration:

'The University of Southampton has built a strong reputation for enterprise using internal funding supplemented by HEIF, SEC, UCF and HEROBC funding. It is one of the world leading Universities for spin outs alongside Stanford and Cambridge (Library House 2007) and is the top UK University for SME Income (HEBCIS 2004-2007).' (HEIF 4, Southampton, 2008)

The KT office at University of Southampton opened in 1992, long before regeneration funding commenced, which helps to explain the enterprise focus.

\section{LEAD - case study of a university regeneration programme}

\section{Impact}

Before examining the specifics of the LEAD programme, the link between such KT activity and economic regeneration of a region needs to be established. Two studies have been undertaken to examine the economic impact of the LEAD programme, motivated at least in part by a contractual need to demonstrate that government funded regeneration programmes have produced sufficiently beneficial results for the regional economy.

The LEAD programme has been evaluated independently by staff from the Business School at University of Newcastle, who found that it had '... strong effects on business outcomes, which have been driven by changes to the business operations of participants'. Firms became more strategic in their approach and the general management of the business was improved: 'about $90 \%$ of firms expect an increase in sales, employment, productivity or profits in the next 2 to 3 years'; 'the firms reported strong increases in the volume of sales, but modest increases in the level of employment, leading to strong increases in productivity growth' (Wren and Jones, 2006, p 2).

The LEAD programme has also been studied by Gordon et al who present evidence of benefits provided to SMEs through engagement in a programme which developed a network '.. of SME owner/managers that is high in trust and where there is evidence of learning taking place through peer to peer activities' (Gordon et al, 2010, $\mathrm{p} \mathrm{10)}$. The programme and the development of a trusted network of peers helped SME owner/ managers to develop their businesses positively. This was not just for the duration of the programme, but through the enduring nature of these networks after the formal programme had ended (Gordon et al, 2010).

There are two motivations for this work relating to the impact of Lancaster University's KT activity. The first is the need to demonstrate effective use of the large amounts of regeneration funding received, particularly from the RDA (because ERDF funded projects have very specific targets). The second motivation relating to KT programmes from the Institute for Entrepreneurship and Enterprise Development (IEED) is the effort to relate KT activity to research and vice versa. This ethos is made clear in the opening statement on the IEED web pages:

'. . the Institute for Entrepreneurship and Enterprise Development (IEED) undertakes outstanding work in the fields of entrepreneurial research, education and business support. Its strengths derive from the close alignment of these three key elements and from the continuous 'real world' feedback that it receives through interaction with the business community. Founding all operations upon the real and current demands of business is fundamental to IEED.' (see Websites, IEED, 2011)

Given the usual routines of university departments and the preference for pure research, which would usually 
distance academic research from KT activity, this is an interesting position because research within IEED feeds on the industry connections brought about through KT engagement with SMEs. The normally conflicting academic and KT agendas co-exist here in a symbiotic relationship.

\section{$L E A D$}

The Institute for Entrepreneurship and Enterprise Development (IEED) is a department within Lancaster University's Management School based in the North West of UK. From the early 1990s the then Entrepreneurship Unit was engaged in teaching entrepreneurship. Its establishment as an Institute in 2003 was built on the philosophy of intertwined research, teaching and outreach. This also reflected government policy, with its growing emphasis on knowledge exchange. In the North West region SMEs represent $98 \%$ of all businesses, with micro-SMEs constituting $89 \%$ of this figure (Small Business Service, 2006). The knowledge transfer work within IEED has focused on this sector, connecting with over 1,000 SMEs since 2001 whilst also developing strong collaborations with Government bodies such as the Regional Development Agency and Business Link. ${ }^{5}$ Cox and Taylor (2006) argue that very little is known about the local and regional economic impact of third mission activity, although there is recognition that higher education can have a critical role as a key driver of productivity growth. A study of the work of IEED identified that for every $£ 1$ spent on the IEED's KT resource, $£ 10$ was created in the region's economy (A D Little, 2003). This evaluation of the regeneration impact of the activity may be considered one of the 'small events' referred to by Kenney and von Burg (2001) since it had a significant influence on the future KT strategy of both the RDA and the university. This work has facilitated an in-depth understanding of the needs of this sector and what type of interventions can provide meaningful support. This learning highlighted that working with the owner-manager (or a decision maker) on their personal development and the strategy of the business had a demonstrable impact on the business's bottom line.

The success of IEED's outreach work and the Government's identification of the need for leadership development led to the North West Development Agency-funded creation of a two-year research and development project focusing on developing the leadership capacity of small businesses. This new path creation, the LEAD programme, was entirely dependent on the availability of the external funding. LEAD was piloted from 2004 to 2006, engaging with nearly 70 owner-managers from micro-SMEs which each

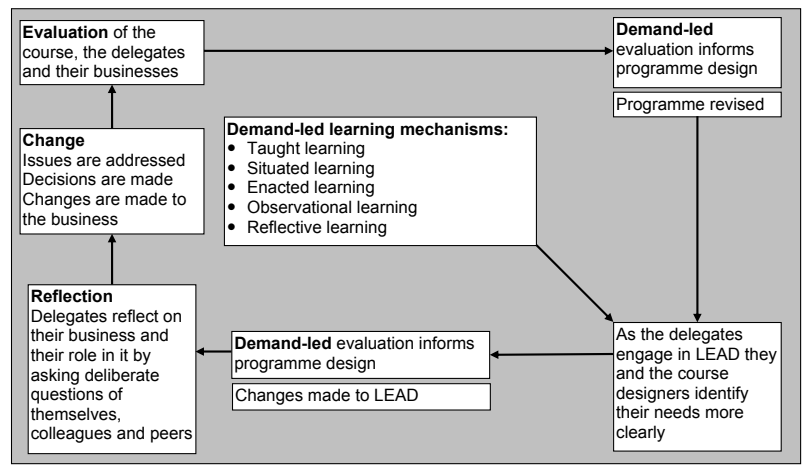

Figure 14. Developing a demand-led programme.

employed fewer than 20 people, to provide learning opportunities for the owner-managers to develop their leadership capabilities. The programme ran as four cohorts with between 16 and 19 delegates in each cohort. The pilot programme was delivered in dialogue with the SME owner-managers to ensure that it met their dynamic needs as leaders of small businesses. This economic sector is under-represented in training programmes with most, if not all, other training programmes being designed for and marketed to managers within larger companies. Training that is available to SME owner-managers tends to consist of elements and methods drawn from corporate training tools demonstrating the dominant routines of universities and their path dependence. Because few courses existed before LEAD that were fundamentally focussed on assisting SMEs, the course designers were required to make assumptions about what methods of learning would suit the LEAD participants best and how these could be best delivered by IEED.

LEAD was designed to be flexible and responsive to the needs of the participants (Smith and Peters, 2006). The sequential nature of the cohort start dates and the ongoing demand-led evaluation enabled formative changes to be made to the programme. In developing the learning mechanisms, the LEAD team recognized the isolated position and lack of training opportunities available to SME owner-managers and developed the programme with a strong emphasis on reflective learning practices. These methods encourage the participants to think more closely about issues and ask themselves questions which could help them resolve problems at work. With few, if any, opportunities to ask others for help or advice, being able to solve one's own problems could prove vital for a small business owner.

In evolutionary terms this process of demand-led design (see Figure 14) demonstrates both a break with university routines of supply side design and a case of path creation. The format of the delivery and the emphasis laid by funding bodies on the economic 
impact suggest that although business support is involved, economic regeneration is the relevant category for this activity in our model. The staff involved act as the entrepreneurs referred to above (Garude and Karnøe, 2001) as they 'meaningfully navigate a flow of events even as they constitute them'.

LEAD has proved to have real economic benefits to the individual companies. The impact of the LEAD programme led to a $£ 10 \mathrm{M}$ extension of LEAD across $13 \mathrm{HE}, \mathrm{FE}$ and private training providers in the North West. It was also being considered by other RDAs, having already been adopted in parts of Wales (but see Note 1). In effect, the programme has become the dominant design for the region referred to by Kenney and von Burg (2001).

\section{Contributions and implications}

This study presents techniques for comparing university engagement in regional regeneration activities. The research makes a particular contribution through the use of evolutionary theory to examine this behaviour, in contrast to more usual university KT practice.

In the UK there has been substantial government investment both in university research and, since the late 1990s, in KT activities. Understanding the influences that affect university relationships within their regions can help to ensure that this investment is beneficial to the UK economy. Also understanding the KT behaviour of universities allows for more effective policy making in this area.

High levels of regeneration activities from UK universities seem to be directly influenced by funding aimed at regeneration. However, it is not clear whether this originated with the receipt of funding or whether university policies to engage actively with regeneration of their regions motivated the decision to use such funding. Some universities in receipt of very little regeneration funding still engage with their region - and make a point of presenting themselves as doing so. Because such regeneration activities would be considered to be unusual in comparison with the normal routines of research and teaching, it is interesting to note this departure and to speculate on the future of these activities.

It is clear that for some universities in the North West of England, in receipt of large amounts of regeneration funding, the regeneration agenda has been adopted as a large part of the KT focus and as their routine pattern of engagement. Interestingly, not all universities in the North West have engaged in regeneration activities, however, as indicated by the number of SME contracts. Those that have engaged state that they have chosen to take this direction - that is, path creation.
In the South East the picture is much less clear. Some universities have adopted a regional regeneration focus, evidenced by their SME engagement and strategy statements, in some cases despite receiving very little regeneration funding. This is particularly interesting as there has been little influence of funding, indicating both path creation and the likelihood that this activity will continue even if funding streams are discontinued.

Work with SMEs is very different to the normal routines of UK universities. Those that have embarked on this course of action have taken a conscious decision - a path creation approach - to change the direction of at least part of their organizational function. This has been encouraged in some cases by regeneration funding programmes; but a comparison of regions with and without large amounts of regeneration funding has shown that it is not funding alone which has brought about this change. Universities in regions without funding also engage with SMEs, albeit in much more limited ways. In addition, not all universities in regions with high levels of available regeneration funding do engage with SMEs.

The case study of the LEAD programme demonstrates evolutionary theory as a useful tool for exploring specific KT activities of a university. It links together the motivation behind the development of the programme, its impact and the influence which has allowed an academic department to embrace successfully both research and regeneration activities in a symbiotic manner.

Overall the UK picture of university engagement with economic development activities is somewhat mixed. However, it does seem clear from this analysis that there is a high level of active decision making, or path creation, in this area. Business support activities, or even the long term regeneration sparked by - often quite unrelated - decisions to spin-off companies over many years, can arise through path dependent processes. The support of regional SMEs, however, seems to require universities to consider their positioning in their regions and to actively engage.

\section{Acknowledgements}

The authors would like to thank the ESRC and AIM for their support of this research project through grant funding for the project 'Knowledge and Technology Transfer, Innovation and Competitive Advantage: Past and Present', ESRC Reference: RES-180-25-0024.

\section{Notes}

${ }^{1}$ Regional Development Agencies (RDAs) for England were established under the Regional Development Agencies Act 1998 and were formally launched in eight English regions on 01 April 1999: the ninth, in London, was established in July 2000. 
However, the present (2011) coalition Government announced the abolition of the nine English RDAs on 22 June 2010 and it is expected that they will cease operations by March 2012. Some functions of the RDAs will be taken up, in part, by new Local Enterprise Partnerships, LEPs, covering smaller geographic areas of the country.

2'The De minimis Regulation covers small amounts of aid within a predetermined threshold ... period which do not count as State aid in the sense of Article 87(1) and are therefore exempt from the notification requirements of the competition rules.' http://wales.gov.uk/topics/businessandeconomy/stateaid/ sarules/deminimis/?lang=en

${ }^{3}$ Answers not included to question 9 - preset table outlining financial breakdown or question 12 - assessment of risks (see HEFCE, 2008a for questions).

${ }^{4}$ Buzz words used: regeneration and/or economic development, regional, Regional Development Agencies (NWDA; SEEDA), SMEs.

${ }^{5}$ The knowledge transfer work has been supported predominantly through funding from the European Regional Development Fund (ERDF), the Higher Education Innovation Fund (HEIF) and through the North West Regional Development Agency. Business Link (a Government-funded advisory service aimed in particular at SMEs) is being closed, as a result of cuts in Government expenditures, in November 2011.

\section{References}

Antonelli, C. (1997), 'The economics of path-dependence in industrial organization', International Journal of Industrial Organization, Vol 15, pp 643-675.

Benneworth, P., and Charles, D. (2005), 'University spin-off policies and economic development in less successful regions: learning from two decades of policy practice', European Planning Studies, Vol 13, No 4, pp 537-557.

Brown, G. (2006), 'Meeting the productivity challenge, a strong and strengthening economy: investing in Britain's future', Budget, 2006, Chapter 3, UK Treasury, HC968, www.official-documents.co.uk.

Chapple, W., Lockett, A., Siegel D., and Wright, M. (2005), 'Assessing the relative performance of U.K. university technology transfer offices: parametric and non-parametric evidence', Research Policy, Vol 34, pp 369-384.

Chell, E., and Oakey, R. (2005), Knowledge creation, its transfer and the role of science enterprise education', in Kauser, S., Oakey, R., and During W., eds, New Technology-Based Firms in the New Millennium, Elsevier, London.

Cox, S., and Taylor, J. (2006), 'The impact of a business school on regional economic development: a case study', Local Economy, Vol 21, No 2, pp 117-135.

Decter, M.H. (2009), 'Comparative review of UK-USA industryuniversity relationships', Education and Training, Vol 51, No 8/9, pp 624-634.

Decter, M., Rose, M., and Cave, F. (2010), 'The shaping of knowledge transfer from UK universities: an exploration of influences and motivations', XXI ISPIM Conference - The Dynamics of Innovation, Bilbao, Spain, 6-9 June 2010.

DTI (2001), Science and Innovation Strategy 2001, Department of Trade and Industry (now Department for Business, Innovation and Skills, BIS), London.

Franklin, S.J., Wright, M., and Lockett, A. (2001), 'Academic and surrogate entrepreneurs in university spin-out companies', Journal of Technology Transfer, Vol 26, No 1-2, pp 127-141.

Garud, R., and Karnøe, P. (2001), 'Path creation as a process of mindful deviation', in Garud, R., and Karnøe, P., eds, Path Dependence and Creation, Lawrence Erlbaum Associates, Mahwah, NJ.

Gordon, I., Hamilton, E., and Jack, S. (2010), 'A study of the regional economic development impact of a university led entrepreneurship education programme for small business owners', Lancaster University Management School Working Papers, Institute for Entrepreneurship and Enterprise Development,http://www.lums.lancs.ac.uk/publications/, last accessed June 2011.

Geuna, A., and Mowery, D. (2007), 'Publishing and patenting in US and European universities', Economics Innovation and New Technology, Vol 16, No 2, pp 67-70.

HEFCE (2006), 'Higher education-business and community interaction survey 2003-4', http://www.hefce.ac.uk/pubs/ hefce/2006/06_25/, last accessed July 2009-February 2010.

HEFCE (2007), 'Higher education-business and community interaction survey 2004-5 and 2005-6', http:// www.hefce.ac.uk/pubs/hefce/2007/07_17/, last accessed April 2008- February 2010.

HEFCE (2008), 'Higher education-business and community interaction survey 2006-07', http://www.hefce.ac.uk/pubs/ hefce/2008/08_22/Accessed July 2009-February 2010.

HEFCE (2008a), 'Higher education innovation fund round 4 invitation and guidance for institutional strategies', http://www.hefce.ac.uk/pubs/hefce/2008/08_02/, last accessed July 2009-February 2010.

HEFCE (2009), 'Higher education-business and community interaction survey 2007-08', http://www.hefce.ac.uk/pubs/ hefce/2009/09_23/, last accessed July 2009-February 2010.

HEFCE (2010) 'Higher education-business and community interaction survey 2008-09',http://www.hefce.ac.uk/pubs/ hefce/2010/10_14/, data available from http:// www.hesa.ac.uk/.

Helfat, C E. (1994), 'Evolutionary trajectories in petroleum firm R\&D', Management Science, Vol 40, No 12, pp 1720-1747.

Hewitt-Dundas, N. (2010), Doing the Business: UniversityBusiness Links and Innovation, NESTA Policy and Research Unit, www.nesta.org.uk, last accessed February 2011.

Hodgson, G. M. (1998), 'The approach of institutional economics', Journal of Economic Literature, Vol XXXVI, pp 166-192.

Holi, M., Franklin, R., Hugo, E., and Lapinski, J. (2007), 'An analysis of the UK university technology and knowledge transfer activities', Library House, www.libraryhouse.net.

Huggins, R., and Johnston A. (2009), 'The economic and innovation contribution of universities: a regional perspective', Environment and Planning C: Government and Policy, Vol 27, pp 1088-1106.

Kenney, M., and von Burg, U. (2001), 'Paths and regions: the creation and growth of Silicon Valley', in Garud, R., and Karnøe, P., eds, Path Dependence and Creation, Lawrence Erlbaum Associates, Mahwah, NJ.

Little, A.D. (2003), 'Expansion of the Lancaster University management school and the Lancaster Leadership Centre: an appraisal of the impacts', Report to North West Development Agency, Arthur D Little, Cambridge.

Lockett, A., and Wright, M. (2005), 'Resources, capabilities, risk capital and the creation of university spin-out companies', Research Policy, Vol 34, pp 1043-1057.

Meyer, M., and Tang, P. (2007), 'Exploring the "value" of academic patents: IP management practices in UK universities and their implications for Third-Stream indicators', Scientometrics, Vol 70, No 2, pp 415-440.

Nelson, R. (2006), 'Evolutionary social science and universal Darwinism', Journal of Evolutionary Economics, Vol 16, pp 491-510.

Nelson, R., and Winter, S. (1982), An Evolutionary Theory of Economic Change, Belknap Press, Cambridge, MA.

Nicolaou, N., and Birley, S. (2003), 'Social networks in organizational emergence: the university spinout phenomenon', Management Science, Vol 49, No 12, pp 1702-1725.

Nooteboom, B. (1997), 'Path dependence and knowledge: implications for the theory of the firm', in Magnusson, L., and Ottosson, J., eds, Evolutionary Economics and Path Dependence, Edward Elgar, Cheltenham. 
NWDA, Northwest Regional Development Agency (2006), Northwest Regional Economic Strategy, http:// www.nwda.co.uk/publications/strategy/regional-economicstrategy-200.aspx, last accessed August 2010.

Office of the Deputy Prime Minister (2001), The European Regional Development Fund - An Introductory Guide, Reference 05RDG03345, reprinted September 2005, Office of the Deputy Prime Minister, available from richard.watkins@odpm.gsi.gov.uk.

Phan, P.H., and Siegel, D.S. (2006), 'The effectiveness of university technology transfer: lessons learned from quantitative and qualitative research in the US and the UK', Rensselaer Working Papers in Economics, Department of Economics, Rensselaer Polytechnic Institute, Troy, NY, http://www.rpi.edu/dept/economics/www/workingpapers/.

Rayson, P. (2003), 'Matrix: a statistical method and software tool for linguistic analysis through corpus comparison', $P h D$ Thesis, Lancaster University, Lancaster.

Rothaermel, F., Agung, D., and Jiang, L. (2007), 'University entrepreneurship: a taxonomy of the literature', Industrial and Corporate change, Vol 16, pp 691-791.

Sainsbury of Turville, Lord (2007), The Race to the Top: A Review of Government's Science and Innovation Policies, HMSO, London.

SEEDA (2006), Regional Economic Strategy 2006-2016: The Evidence Base, South East England Development Agency, October 2006, http://www.seeda.co.uk/_documentbank/ RES2006_16_EvidenceBase.pdf, accessed July 2011.

Shattock M. (2009), 'Research, technology and knowledge transfer', in Shattock M., ed, Entrepreneurialism in Universities and the Knowledge Economy - Diversification and Organizational Change in European Higher Education, Chapter 3, pp 33-48, Society for Research in Higher Education and Open University Press, Maidenhead.

Smith, L., and Peters, S. (2006), 'Leading by design: the case of LEAD', paper for Entrepreneurial Leadership Learning Symposium (Belfast), British Academy of Management, London.

Wren, C., and Jones, J. (2006), Ex-post Evaluation of the LEAD Programme, IEED, Lancaster University, Lancaster.

\section{Websites}

Individual university websites, for background information

University of Brighton, http://www.brighton.ac.uk/, accessed August 2010.

Buckinghamshire New University, http://bucks.ac.uk/, accessed August 2010.

University of Central Lancashire website, http:// www.uclan.ac.uk/, accessed August 2010.

University of Lancaster, http://www.lancs.ac.uk/, accessed August 2010.

University of Portsmouth, http://www.port.ac.uk/ and http://www.port.ac.uk/aboutus/economicimpact/, accessed August 2010.

University of Salford, http://www.salford.ac.uk/, accessed August 2010.

University of Southampton, http://www.soton.ac.uk/, accessed August 2010.

Other websites

Higher Education Statistics Agency (HESA) statistics, 'Table R1 - Share of research output per share of research input, weighted by cost centre 2006/07', http://www.hesa.ac.uk/, accessed June 2009.

Research Assessment Exercise (REA), THES interpretation, http://www.timeshighereducation.co.uk/Journals/THE/THE/ 18_December_2008/attachments/RAE_2008_THE_ RESULTS.pdf, accessed December 2008.

Small Business Service, http://www.sbs.gov.uk/, accessed January 2006.

De Minimis Regulation, http://wales.gov.uk/topics/ businessandeconomy/stateaid/sarules/deminimis/?lang=en.

THES, 'Times Higher Education Table of Excellence', http://www.timeshighereducation.co.uk/Journals/THE/THE/ 18_December_2008/attachments/RAE_2008_THE_ RESULTS.pdf, accessed December 2008.

\section{University annual reports}

University of Brighton Annual Report, http://www.brighton.ac.uk/ annualreport/index.php?Pageld $=404$, accessed JanuaryFebruary 2010.

Buckinghamshire New University Annual Report, http://bucks.ac.uk/about/structure/directorates/finance.aspx, accessed August 2010.

University of Central Lancashire Annual Report, http://www.uclan.ac.uk/information/services/finance/ accounting/2008/expenditure_account.php accessed January-February 2010.

Lancaster University Annual Report, http://www.lancs.ac.uk/ press/annualreport.htm accessed Jan-Feb. 2010

University of Portsmouth, Annual Report, http://www.port.ac.uk/ aboutus/corporatepublications/, accessed August 2010.

University of Salford Annual Report, http:// www.corporate.salford.ac.uk/annual-report/. accessed November-December 2007 and September-October 2009.

University of Southampton Annual Report, http:// www.soton.ac.uk/about/publications/index.html,

\section{HEIF Strategies}

General website:

HEIF 4 Strategies, Institute of Knowledge Transfer, http://www.ikt.org.uk/, accessed April 2009.

University strategies, all accessed April 2009:

HEIF 4 Strategy, University of Brighton

HEIF 4 Strategy, UCLAN

HEIF 4 Strategy, University of Lancaster

HEIF 4 Strategy, University of Salford

HEIF 4 Strategy, Buckinghamshire New University

HEIF 4 Strategy, University of Portsmouth.

HEIF 4 Strategy, University of Southampton

\section{Interviews with universities}

(Full details are available from the authors)

- University of Brighton, 2009

- Lancaster University, 2009

- University of Salford, 2007

- University of Surrey, 2008

- UCLAN, 2010 